University of Nebraska - Lincoln

DigitalCommons@University of Nebraska - Lincoln

Faculty Publications, Department of Psychology

Psychology, Department of

$10-2014$

Differential effects of intermittent versus continuous haloperidol treatment throughout adolescence on haloperidol sensitization and social behavior in adulthood

Jun Gao

University of Nebraska-Lincoln

Ming Li

University of Nebraska-Lincoln, mli2@unl.edu

Follow this and additional works at: http://digitalcommons.unl.edu/psychfacpub

Part of the Animal Studies Commons, Biological Psychology Commons, and the Social Psychology Commons

Gao, Jun and Li, Ming, "Differential effects of intermittent versus continuous haloperidol treatment throughout adolescence on haloperidol sensitization and social behavior in adulthood" (2014). Faculty Publications, Department of Psychology. 687.

http://digitalcommons.unl.edu/psychfacpub/687

This Article is brought to you for free and open access by the Psychology, Department of at DigitalCommons@University of Nebraska - Lincoln. It has been accepted for inclusion in Faculty Publications, Department of Psychology by an authorized administrator of DigitalCommons@University of Nebraska - Lincoln. 
Published in final edited form as:

Prog Neuropsychopharmacol Biol Psychiatry. 2014 October 3; 0: 67-75. doi:10.1016/j.pnpbp. 2014.05.015.

\title{
Differential Effects of Intermittent versus Continuous Haloperidol Treatment throughout Adolescence on Haloperidol Sensitization and Social Behavior in Adulthood
}

\author{
Jun Gao and Ming $\mathbf{L i}^{*}$ \\ Department of Psychology, University of Nebraska-Lincoln, USA
}

\section{Abstract}

\begin{abstract}
Animal work on the behavioral effects of antipsychotic treatment suggests that different dosing regimens could affect drug sensitivity differently, with an intermittent treatment regimen tending to cause a sensitization effect, while a continuous treatment causing a tolerance. In this study, we explored how haloperidol (HAL) sensitization induced throughout adolescence and tested in adulthood was differentially impacted by these two dosing regimens in the conditioned avoidance response (CAR) test. We also examined how these two dosing regiments affected social interaction and social memory in adulthood. Male adolescent Sprague-Dawley rats were treated with HAL via either osmotic minipump (HAL-0.25 CONT; $0.25 \mathrm{mg} / \mathrm{kg} /$ day, $\mathrm{n}=14$ ) or daily injection (HAL-0.05 INT; $0.05 \mathrm{mg} / \mathrm{kg} /$ injection/day, sc, $\mathrm{n}=14)$, or sterile water $(\mathrm{n}=14)$ from postnatal days (PND) 44 to 71. HAL sensitization was assessed in a challenge test in which all rats were injected with HAL ( 0.025 and $0.05 \mathrm{mg} / \mathrm{kg}$, sc) on PND 80 and PND 82. Two days later, half of the rats from each group ( $\mathrm{n}=7$ /group) were assayed in two 4-trial social interaction tests in which a subject rat was given four 5-min social encounters with a familiar or novel juvenile rat (PND 35-40) at $10 \mathrm{~min}$ intervals. Another half were tested in a quinpirole-induced hyperlocomotion assay to assess the potential HAL-induced change in $\mathrm{D}_{2}$-mediated function. Results show that only the intermittent dosing group under the HAL $0.05 \mathrm{mg} / \mathrm{kg}$ challenge showed a robust sensitization effect as rats in this group made significantly fewer avoidance responses than those in the vehicle and HAL-0.25 CONT groups. Adolescent HAL treatment did not affect social behavior and social memory, as rats from all 3 groups exhibited a similar level of social interaction and showed a similar level of sensitivity to the change of social stimuli. Similarly, adolescent HAL treatment also did not produce a long-lasting change in $\mathrm{D}_{2}$ function, as all 3 groups exhibited a similar level of increase in motor activity under quinpirole challenge. These findings suggest that HAL sensitization is a dosing-specific phenomenon. It is more likely to be seen under an intermittent dosing regimen than under a continuous dosing one. The findings that the intermittent HAL treatment did not impair social functioning and did not alter $\mathrm{D}_{2}$ function
\end{abstract}

(C) 2014 Elsevier Inc. All rights reserved.

*Corresponding author: Ming Li, PhD, Associate Professor, Department of Psychology, University of Nebraska-Lincoln, 238 Burnett Hall, Lincoln, NE 68588-0308, USA., Telephone: 402-472-3144. mli2@unl.edu.

Publisher's Disclaimer: This is a PDF file of an unedited manuscript that has been accepted for publication. As a service to our customers we are providing this early version of the manuscript. The manuscript will undergo copyediting, typesetting, and review of the resulting proof before it is published in its final citable form. Please note that during the production process errors may be discovered which could affect the content, and all legal disclaimers that apply to the journal pertain.

Conflicts of interest: None 
suggest a dissociation between drug-induced alterations in drug sensitivity and those in social function and neuroreceptors.

\section{Keywords}

Antipsychotic drug; Sensitization; Adolescence; Conditioned avoidance response; Haloperidol; Social behavior

\section{Introduction}

Recent work suggests that adolescent antipsychotic exposure could alter antipsychotic response in adulthood (Qiao et al., 2014a, Qiao et al., 2013, Shu et al., 2014). Two patterns of such alterations have been identified and named antipsychotic sensitization and tolerance from adolescence to adulthood. Antipsychotic sensitization from adolescence to adulthood refers to the increased effectiveness of a given antipsychotic drug to alter behavioral and brain functions assessed in adulthood due to past drug experience in adolescence, whereas antipsychotic tolerance refers to the opposite response pattern (i.e. decreased effectiveness due to past drug exposure). In the clinic, supersensitivity psychosis, tardive dyskinesia, and time-dependent increase in antipsychotic efficacy are several well-known examples of antipsychotic sensitization and tolerance (Agid et al., 2003, Fallon and Dursun, 2011, Kapur et al., 2006). However, clinical examples reflecting the sensitization and tolerance across the developmental period are less understood and currently understudied.

Many researchers use a rat conditioned avoidance response (CAR) test to measure antipsychotic efficacy (Arnt, 1982, Wadenberg and Hicks, 1999). In a typical CAR paradigm, a rat is placed in a two-compartment box and trained daily to make a motor response (e.g. shuttling between two compartments) to avoid a footshock when it hears a sound. The sound typically precedes the shock for a few seconds (10 s). Antipsychotic drugs can be administered before the acquisition of avoidance responding or after. Studies over the past 60 years have consistently shown that at clinically relevant doses, all clinically approved antipsychotic drugs acutely suppress the acquisition and expression of avoidance response (Arnt, 1982, Wadenberg et al., 2001). Our CAR work has been focusing on the repeated effects of drug administration. We show that adult rats that had been treated with olanzapine or risperidone in adolescence responded to these drugs in a more sensitive way than those treated with vehicle (Qiao, Gao, 2014a, Qiao, Li, 2013), whereas adult rats that had been treated with clozapine in adolescence responded to this drug in a less sensitive way than those treated with vehicle (Qiao, Li, 2013). Specifically, in a single avoidance challenge test in which all rats were injected with a low dose of olanzapine or risperidone, adult rats that had been treated with these drugs for only 5 days in adolescence showed much lower avoidance responding than those previously treated with vehicle, whereas those treated with clozapine tended to have higher avoidance. We further show that adolescent risperidone treatment could even enhance sensitivity to olanzapine treatment in adulthood (Qiao et al., 2014b). From these studies, it becomes quite clear that antipsychotic treatment in adolescence can induce a long-term change in drug responsiveness that persists into adulthood. 
Much of our adolescent antipsychotic sensitization and tolerance work has relied on a daily intermittent drug injection schedule for a short period of time (e.g. 5 days). Whether this effect is subject to change in magnitude has never been examined. Given that drug dosing regimens determine many features of long-term treatment outcomes, with an intermittent treatment tending to cause a sensitization effect while a continuous treatment causing a tolerance (Remington and Kapur, 2010), it is quite possible that antipsychotic sensitization would be different under the two dosing regimens. This notion is consistent with evidence in the literature. For example, it has been shown that continuous haloperidol or olanzapine exposure to rats via osmotic minipump caused a greater increase in vacuous chewing movements (VCMs, a proxy for tardive dyskinesia in humans) than transient subcutaneous injections (Turrone et al., 2005). Similarly, continuous haloperidol treatment resulted in increased amphetamine-induced locomotor activity following antipsychotic discontinuation (a measure of supersensitivity psychosis) and caused an attenuated disruption (tolerance) of avoidance responding (a measure of antipsychotic activity). In contrast, intermittent haloperidol treatment did not cause an increased sensitivity to amphetamine challenge and it actually potentiated avoidance disruption (sensitization) (Samaha et al., 2008, Samaha et al., 2007). Thus, the primary goal of the present study was to investigate whether continuous haloperidol treatment in adolescence could induce a sensitization that differs from the one induced by intermittent haloperidol treatment, and whether this sensitization effect was mediated by drug-induced dopamine $\mathrm{D}_{2}$ supersensitivity, as previously shown in the risperidone-induced sensitization ( $\mathrm{Gao}$ and $\mathrm{Li}, 2013$ ).

Adolescent antipsychotic treatment is known to exert long-term impacts of basic behavioral and brain functions. Several studies demonstrate that early adolescent antipsychotic exposure causes an impairment of animals' working memory and delays the extinction process of fear memory in adulthood (Milstein et al., 2013). It is effective in preventing the development of various psychosis-like behaviors (e.g. prepulse inhibition deficit, latent inhibition deficit, etc.) induced by maternal immune activation (PolyI:C injection during pregnancy), while impairing certain behavioral functions of normal animals (Meyer et al., 2010, Piontkewitz et al., 2011, Piontkewitz et al., 2009, Piontkewitz et al., 2012). However, no studies have examined whether adolescent antipsychotic treatment would affect social functioning in adulthood, one of seven primary cognitive domains that are affected in schizophrenia (Floresco et al., 2005, Green et al., 2004). Therefore, the secondary goal of this study was to examine how intermittent and continuous haloperidol treatment may potentially impact social interaction and social memory used a paradigm that we validated in amphetamine and phencyclidine-based animal models of schizophrenia (Li et al., 2012a). Findings from this study could help determine the clinical significance of adolescent haloperidol sensitization and enhance our understanding of the positive and negative impacts of adolescent antipsychotic treatment on drug response and behavioral functions.

\section{Materials and methods}

\subsection{Animals}

Adolescent male Sprague-Dawley rats $(\mathrm{n}=72$, postnatal days, PND 25-27 upon arrival, averaged age were assumed to be PND 26) were purchased from Charles River Inc.

Prog Neuropsychopharmacol Biol Psychiatry. Author manuscript; available in PMC 2015 October 03. 
(Portage, MI). They were housed two per cage, in $39.5 \mathrm{~cm} \times 34.6 \mathrm{~cm} \times 21.3 \mathrm{~cm}$ transparent polycarbonate cages under 12-h light/dark conditions (light on between 6:30 am and 6:30 pm). Room temperature was maintained at $22 \pm 1{ }^{\circ} \mathrm{C}$ with a relative humidity of $45-60 \%$. Food and water was available ad libitum. Animals were allowed at least 5 days of acclimation to the animal facility before being used in experiments. All behavioral tests took place between 9 am and $4 \mathrm{pm}$ in the light cycle. All experimental treatment and procedures were approved by the Institutional Animal Care and Use Committee at the University of Nebraska-Lincoln.

\subsection{Drugs and choice of doses}

Haloperidol (HAL) is dopamine $\mathrm{D}_{2}$ receptor antagonist (Strange, 2001). HAL $(5.0 \mathrm{mg} / \mathrm{ml}$ Ampoules, Shanghai Xudong Haipu Pharmaceutical Co. Ltd, Shanghai, China) was dissolved in distilled sterile water. Quinpirole hydrochloride (Tocris Bioscience, Bristol, UK) was dissolved in $0.9 \%$ saline. All drugs were administered subcutaneously in a volume of $1.0 \mathrm{ml} / \mathrm{kg}$ body weight. The continuous and intermittent treatment doses of HAL were based on the rat striatal $\mathrm{D}_{2}$ receptor occupancy data (65-80\%) that corresponds to clinically relevant conditions (Kapur et al., 2003) and prior studies using the conditioned avoidance response task (Samaha, Reckless, 2008, Samaha, Seeman, 2007) and social behavior (Li et al., 2005). The doses of quinpirole (a selective dopamine $\mathrm{D}_{2 / 3}$ receptor agonist) were chosen based on previous work showing that this dose was effectively induced hyperactivity, and to assess $\mathrm{D}_{2}$ receptor-mediated motor activity (Gao and Li, 2013, Luque-Rojas et al., 2013, Nakamura et al., 1994, Qiao, Gao, 2014a).

\subsection{Two-way avoidance conditioning apparatus}

Ten identical two-way shuttle boxes custom designed and manufactured by Med Associates (St. Albans, VT) were used. Each box was housed in a ventilated, sound-insulated isolation cubicle $(96.52 \mathrm{~cm} \mathrm{~W} \times 35.56 \mathrm{~cm} \mathrm{D} \times 63.5 \mathrm{~cm} \mathrm{H})$. Each box was $64 \mathrm{~cm}$ long, $30 \mathrm{~cm} \mathrm{high}$ (from grid floor), and $24 \mathrm{~cm}$ wide, and was divided into two equal-sized compartments by a partition with an arch style doorway $(15 \mathrm{~cm}$ high $\times 9 \mathrm{~cm}$ wide at base). A barrier $(4 \mathrm{~cm} \mathrm{high)}$ was placed between the two compartments, so the rats had to jump from one compartment to the other. The grid floor consisted of 40 stainless-steel rods with a diameter of $0.48 \mathrm{~cm}$, spaced $1.6 \mathrm{~cm}$ apart center to center, through which a scrambled footshock (unconditioned stimulus, US; $0.8 \mathrm{~mA}$, maximum duration: $5 \mathrm{~s}$ ) was delivered by a constant current shock generator (Model ENV-410B) and scrambler (Model ENV-412). The rat location and crossings between compartments were monitored by a set of 16 photobeams (ENV-256-8P) affixed at the bottom of the box ( $3.5 \mathrm{~cm}$ above the grid floor). Illumination was provided by two houselights mounted at the top of each compartment. The conditioned stimulus (CS; i.e. $76 \mathrm{~dB}$ white noise) was produced by a speaker (ENV $224 \mathrm{AMX}$ ) mounted on the ceiling of the cubicle, centered above the shuttle box. Background noise (approximately $74 \mathrm{~dB}$ ) was provided by a ventilation fan affixed at the top corner of each isolation cubicle. All training and testing procedures were controlled by Med Associates programs running on a computer. 


\subsection{Locomotor activity monitoring apparatus}

Sixteen activity boxes were used to assess quinpirole-induced hyperlocomotion as a means to detect possible HAL-induced $\mathrm{D}_{2}$ receptor supersensitivity. They were housed in a quiet room. The boxes were $48.3 \mathrm{~cm} \times 26.7 \mathrm{~cm} \times 20.3 \mathrm{~cm}$ transparent polycarbonate cages, which were similar to the home cages but were each equipped with a row of 6 photocell beams ( 7.8 $\mathrm{cm}$ between two adjacent photobeams) placed $3.2 \mathrm{~cm}$ above the floor of the cage. A computer with recording software (Aero Apparatus Sixbeam Locomotor System v1.4, Toronto, Canada) was used to detect the disruption of the photocell beams and recorded the number of beam breaks. All experiments were run during the light cycle.

\subsection{Experiment 1: Differential effects of intermittent versus continuous haloperidol treatment in adolescence on haloperidol sensitization in the conditioned avoidance response task}

The experiment was comprised of three phases (see Fig. 1 for the general experimental procedure): Avoidance training in CAR in adolescence, Minipump implantation, Repeated $H A L$ testing during the treatment period in adolescence, Avoidance retraining and HAL challenge test in adulthood.

Avoidance training in CAR in adolescence-Sixty rats ( PND 31$)$ were first habituated to the CAR boxes for 2 days ( $30 \mathrm{~min} /$ day) and then trained for conditioned avoidance responding for 10 consecutive days/sessions. Each session consisted of 30 trials and every trial started with a white noise (CS) to be presented for $10 \mathrm{~s}$, immediately followed by a continuous scrambled foot shock $(0.8 \mathrm{~mA}$, US, maximum duration $=5 \mathrm{~s})$ to be delivered on the grid floor. If a subject ran from one compartment into the other within the $10 \mathrm{~s}$ of CS presentation, it avoided the shock and this shuttling response was recorded as avoidance. If the rat remained in the same compartment for more than $10 \mathrm{~s}$ and made a crossing upon receiving the footshock, this response was considered as escape. If the rat did not respond during the entire $5 \mathrm{~s}$ presentation of the shock, the trial was terminated and the intertrial interval was initiated ( $30-60 \mathrm{~s})$. The total number of avoidance responses as the measure of antipsychotic activity was recorded for each session.

Minipump implantation-At the end of the training session, 42 rats acquired a robust avoidance responding ( $\geq 50 \%$ avoidance in each of the last 2 sessions). They were first matched on avoidance performance on the last training day (i.e., predrug) to create blocks of rats ( $\mathrm{n}=3$ rats/block) that had approximately equal number of avoidance response. Within each block, they were then randomly assigned to 1 of 3 groups ( $n=14$ /group): VEH (vehicle, sterile water), HAL-0.05 INT (Intermittent haloperidol $0.05 \mathrm{mg} / \mathrm{kg}$, sc), or HAL-0.25 CONT (HAL $0.25 \mathrm{mg} / \mathrm{kg} /$ day delivered via minipumps). One day after the $10^{\text {th }}$ CAR training session, rats were anaesthetized under $1.5 \%$ isoflurane and were implanted with osmotic pumps (model 2ML4, ALZET osmotic minipumps, Cupertino, CA, the treatment duration can last up to 28 days) containing either sterile water (VEH) or HAL. A $1.5-\mathrm{cm}$-wide incision was made in each animal's lower back and hemostats were used to loosen connective tissue between the scapulae. Minipumps were wiped with $75 \%$ ethanol and inserted to lie between the scapulae with the flow moderator away from the incision. The incision was closed using $9 \mathrm{~mm}$ surgical staples and cleaned with $75 \%$ ethanol. 
Repeated HAL testing during the treatment period in adolescence-Starting on day 3 of drug treatment, all rats were tested for avoidance responding daily under the CSonly (no shock, 30 trials/session) for 5 consecutive days (i.e., until day 7 of treatment), followed by 7 periodic tests on days 10,13,16,18, 21, 24, and 27 of treatment. On each test day, rats were first injected with sterile water (for the HAL-0.25 CONT and VEH groups) or HAL $0.05 \mathrm{mg} / \mathrm{kg}$ (for the HAL-0.05 INT group). One hour later, they were placed in the CAR boxes and tested. On the days when rats were not tested, injections were given in their home cages. One day after the last avoidance test, the minipumps were taken out from all rats under $1.5 \%$ isoflurane anesthesia.

Avoidance retraining and HAL challenge test in adulthood-Two days later ( PND 75-79), all rats were returned to the CAR boxes for 5 days of CAR retraining under the CS-US condition (30 trials, shock) to ensure all groups had a comparable level of avoidance responding before the sensitization assessment. The $1^{\text {st }}$ HAL sensitization was assessed 1 day after the $5^{\text {th }}$ training session ( PND 80) with all rats being injected with a challenge dose of HAL $0.025 \mathrm{mg} / \mathrm{kg}$ and tested for avoidance performance in the CS-only condition (30 trials, no shock) $1 \mathrm{~h}$ later. The $2^{\text {nd }} \mathrm{HAL}$ sensitization test occurred 2 days later ( PND 82) after another 1 retraining session (CS-US, 30 trials). All rats were challenged with $\mathrm{HAL}$ at $0.05 \mathrm{mg} / \mathrm{kg}$.

\subsection{Experiment 2: Possible long-term effects of intermittent versus continuous haloperidol treatment in adolescence on social behavior in adulthood}

Two days after the last challenge test (see Fig. 1 for the general experimental procedure), all rats were tested for social interaction as described previously ( $\mathrm{Li}, \mathrm{He}, 2012 \mathrm{a})$. The test was one in a quiet test room. Twenty-one rats randomly selected from 42 used in Experiment 1 were tested in this experiment. They included 7 rats from each of the 3 groups: VEH, HAL-0.05 INT, or HAL-0.25 CONT. Twelve adolescent rats (PND 35) were used as test partners and housed separately from the subjects. The subject rats and test partners were first habituated to 4 large transparent observation cages $(51 \mathrm{~cm} \times 38.1 \mathrm{~cm} \times 19 \mathrm{~cm})$ for 2 days. On each habituation day, a rat was first taken to the test room for $30 \mathrm{~min}$, and then placed into the test cage with wood shavings for bedding for $10 \mathrm{~min}$. One day after the habituation, each subject rat received two consecutive days of social interaction and social memory test. On each test day, the subject was first placed into an observation cage. Ten minutes later, the adolescent test partner was introduced, and their behaviors were videotaped for $5 \mathrm{~min}$, after which the test partner was removed and returned to a separate holding cage. This procedure was repeated 3 additional times at 10-min intervals, thereby giving every subject four 5-min test sessions per day. On Day 1, each subject was tested with the same partner in all 4 sessions. This day was termed the "AAAA" day, denoting that the four 5-min tests used the same "A" partner. On Day 2, each subject rat was again tested with the previous partner ("A") in the first 3 sessions but with a new partner ("B") in the final session. This day was termed the "AAAB" day.

The amount of time (in seconds, $300 \mathrm{~s}$ max) that a subject rat engaged in social interaction, including sniffing (whole body and anogenital area), climbing over and crawling underneath the partner, grooming, and closely following its partner $(<2-5 \mathrm{~cm})$, was later scored by two 
trained raters using JWatcher behavioral coding software (http://www.jwatcher.ucla.edu/). Please note that any social contact initiated by the partner was not counted to ensure an accurate recording of only the social interaction initiated by the subject. The results from each rater were compared and used only one since the correlation is very high $(\mathrm{r}>0.987, p<$ 0.001). We used the total time spent on social interaction (e.g. sniffing, chasing, following) and used it for data analysis. To evaluate the social interaction time changes across the 4 test sessions on each test day, we also calculated the percentage of social interaction time of each individual rat spent in the test sessions 2-4 relative to its time spent in the session 1 . Social memory was indexed by the across-session, progressive decline in the time spent on social interaction on the AAAA day, and the initial decline in the first three sessions and recovery of the interaction time in the last session on the AAAB day.

\subsection{Experiment 3: Possible long-term effects of intermittent versus continuous haloperidol treatment in adolescence on quinpirole-induced hyperlocomotion}

In this experiment, we assessed the potential HAL-induced functional changes in dopamine $\mathrm{D}_{2}$ receptors in the quinpirole-induced hyperlocomotion test. The remaining 21 rats $(\mathrm{n}=7$ from each group) used in Experiment 1 but not used in the social behavior test were tested in this experiment. The test started 6 days after the $2^{\text {nd }}$ HAL challenge test (see Fig. 1 for the general experimental procedure). Rats were first habituated to the locomotor activity apparatus for 1 day (30 min/day). Next day, they were first injected with quinpirole $(0.2$ $\mathrm{mg} / \mathrm{kg}$ ) and immediately being placed in the test apparatus for $120 \mathrm{~min}$. One day later, all rat were habituated and tested again with quinpirole at $1.0 \mathrm{mg} / \mathrm{kg}$. Locomotor activity (number of photebeam breaks) was measured in 10-min intervals throughout the entire 120-min test session.

\subsection{Statistical Analysis}

All data are expressed as mean + SEM. Data from the drug test sessions and retraining sessions (e.g. avoidance response) were analyzed using a split-plot analysis of variance (ANOVA) with the between-subjects factor being drug group and the within-subjects factor being test session. Differences between groups on the specific drug test days were analyzed using one-way ANOVAs followed by post hoc Tukey's HSD tests. Split-plot repeated measures ANOVA was also used for analyzing locomotor activity and social interaction time across each session, with drug group and time block (or test session) as between- or within-subjects factors, respectively. Data from the challenge tests and total locomotor activity on each test day were analyzed using a one-way ANOVA with treatment (VEH, HAL-0.05 INT, or HAL-0.25 CONT) as between-subjects factors, followed by post hoc Tukey's HSD tests. Significance was predetermined at $p<0.05$. One rat in Experiment 1 was excluded from data analysis, because it showed less than $70 \%$ avoidance during the final retraining day. All data was analyzed using SPSS Version 22. 


\section{Results}

\subsection{Experiment 1: Differential effects of intermittent versus continuous haloperidol treatment in adolescence on haloperidol sensitization in the conditioned avoidance response task}

Avoidance response during the repeated HAL test period-As showed in Fig. 2, avoidance responding was initially suppressed in both the HAL-0.05 INT and HAL-0.25 CONT groups relative to the predrug day (i.e. the $10^{\text {th }} \mathrm{CAR}$ training day) and vehicle levels, and this suppression was greater in the HAL-0.05 INT group than the HAL-0.25 CONT group. A split-plot ANOVA of the 5 test days revealed a significant main effect of group $[F(2,38)=174.356, p<0.001]$, session $[F(4,152)=12.194, p<0.001]$, and a significant interaction between the two $[F(8,152)=8.313, p<0.001]$. Post hoc Tukey's HSD tests revealed a significant suppressive effect of HAL treatment in both HAL-0.05 INT and HAL-0.25 CONT groups (both $p<0.001$ ), but no significant difference between the two ( $p$ $=0.272$ ). One-way ANOVAs followed by post hoc Tukey's tests on each test day revealed that the HAL-0.05 INT and HAL-0.25 CONT groups had significantly lower avoidance than the VEH group on all 5 days ( $p s<0.001$ ), while the HAL-0.05 INT group had significantly lower avoidance than the HAL-0.25 CONT group on the drug test days 3-5 ( $p=0.02,0.001$, and 0.003 on days $3-5)$, suggesting a greater suppression effect by intermittent HAL $(0.05$ $\mathrm{mg} / \mathrm{kg}$ ) injection.

A split-plot ANOVA of the remaining 7 periodic avoidance drug tests also revealed a significant main effect of group $[F(2,38)=227.688, p<0.001]$, session $[F(6,228)=3.518, p$ $=0.002]$, and a significant interaction between the two $[F(12,228)=3.405, p<0.001]$. Post hoc Tukey's HSD tests revealed a significant suppressive effect of HAL treatment in both the HAL-0.05 INT and HAL-0.25 CONT groups (both $p<0.001$ ), in addition to a significant greater suppressive effect by HAL-0.05 INT compared to the HAL-0.25 CONT $(p<0.001)$. One-way ANOVA followed by post hoc Tukey's tests on each test day revealed that the HAL-0.05 INT and HAL-0.25 CONT groups had significantly lower avoidance than the VEH group on all 7 test days ( $p s<0.001$ ), while the HAL-0.05 INT group had significantly lower avoidance than the HAL- 0.25 CONT group on the test days 10, 13 ( $p=$ $0.017,0.002$, respectively), and on the final 5 test days (all $p s<0.001$ ).

Avoidance response on the retraining and challenge test-Fig. 3 shows the number of avoidance responses on the last drug test (the $7^{\text {th }}$ periodic test) day and throughout the 5 avoidance retraining days. All 3 groups improved their avoidance relative to their performance on the last drug day (paired t tests, all $p s<0.001$ ), and re-acquired avoidance responding at a similar rate over the 5 retraining days, although HAL-0.05 INT group had lower avoidance response on day 1. A split-plot ANOVA of the 5 retraining days revealed a significant main effect of group $[F(2,38)=3.758, p=0.032]$, session $[F(4,152)=$ $26.447, p<0.001]$, and a significant interaction between the two $[F(8,152)=5.504, p<$ 0.001]. Post hoc Tukey's HSD tests revealed a significant suppressive effect of HAL treatment in HAL-0.05 INT group than HAL-0.25 CONT group ( $p=0.050)$, but no significant difference between the two HAL groups and VEH group ( $p s>0.068)$. One-way ANOVA followed by post hoc Tukey's tests on each test day revealed that the HAL-0.05 
INT group had significantly lower avoidance than the VEH $(p=0.002)$ and HAL- 0.25 CONT ( $p=0.006$ ) groups only on the retraining day 1 . No significant group difference was found on days 2-5, thus the adolescent HAL intermittent transiently impaired the memory of avoidance responding. It also suggests that the HAL intermittent treatment had a longerlasting impact on avoidance responding than the continuous treatment.

Fig. 4A shows the number of avoidance responses on the $5^{\text {th }}$ retraining (predrug) day and the HAL $(0.025 \mathrm{mg} / \mathrm{kg})$ challenge day. One way ANOVA found no significant group difference on the predrug day $[F(2,38)=1.573, p=0.221]$. On the challenge day when all rats were injected with HAL $0.025 \mathrm{mg} / \mathrm{kg}$, the HAL-0.05 INT group made fewer avoidance responses than the VEH and HAL-0.25 CONT groups, but this difference was not statistically significant [the main effect of group, $F(2,38)=2.293, p=0.115$ ]

One day later, all rats were retrained drug-free for 1 session, and then challenged with HAL at $0.05 \mathrm{mg} / \mathrm{kg}$. Fig. 4B shows the number of avoidance responses on the retraining (predrug) day and the HAL challenge $(0.05 \mathrm{mg} / \mathrm{kg})$ day. No significant group difference was found on the predrug day $[F(2,38)=0.737, p=0.550]$. However on the challenge day when all rats were injected with HAL $0.05 \mathrm{mg} / \mathrm{kg}$, the HAL-0.05 INT group made significantly fewer avoidance responses compared to the VEH and HAL-0.25 CONT groups. One-way ANOVA confirmed a main effect of group $[F(2,38)=434.088, p<0.001]$. Post hoc Tukey's HSD tests showed that the HAL-0.05 INT group, but not the HAL-0.25 CONT group, was significantly different from the VEH group ( $p=0.004,0.820$, respectively), and the HAL-0.05 INT group was also significantly different from the HAL-0.25 CONT group ( $p=$ 0.001 ). These data suggests that chronic intermittent but not continuous HAL treatment in adolescence produced a sensitization effect.

\subsection{Experiment 2: Possible long-term effects of intermittent versus continuous haloperidol treatment in adolescence on social behavior in adulthood}

Fig. 5A shows the time spent on social interaction on each session on the 2 test days (the AAAA and AAAB test) for each treatment group. Adolescent intermittent or continuous HAL treatment did not seem to affect social behavior. On the AAAA day, a split-plot ANOVA revealed a significant effect of session $[F(3,54)=55.625, p<0.001]$, but no significant effect of group $[F(2,18)=0.474, \mathrm{p}=0.630]$, nor the interaction between the two $[F(6,54)=1.648, p=0.152]$. Similarly, on the AAAB day, only the main effect of session was significant $[F(3,54)=17.179, p<0.001]$, but no effect of $\operatorname{group}[F(2,18)=0.578, p=$ $0.571]$ or group $\times$ session interaction $[F(6,54)=0.750, p=0.612]$ was significant.

Fig. 5B shows the percentages of social interaction time of each individual rat spent in sessions 2-4 relative to that in session 1. Again, the session effect was apparent. On the AAAA day, a split-plot ANOVA revealed a significant effect of session $[F(3,54)=57.118$, $p<0.001]$, but no significant effect of group $[F(2,18)=0.932, p=0.412]$, nor the interaction between the two $[F(6,54)=1.415, p=0.226]$. Similarly, on the AAAB day, only the main effect of session was significant $[F(3,54)=16.023, p<0.001]$, but not the effect of group $[F(2,18)=1.668, \mathrm{p}=0.217]$ nor group $\times$ session interaction $[F(6,54)=0.971, p=$ 0.454]. 


\subsection{Experiment 3: Possible long-term effects of intermittent versus continuous haloperidol treatment in adolescence on quinpirole-induced hyperlocomotion}

In the quinpirole-induced hyperlocomotion test, adult rats that were treated with HAL-(0.05 INT and 0.25 CONT) or vehicle throughout the adolescent period were challenged with quinpirole at 0.2 and $1.0 \mathrm{mg} / \mathrm{kg}$ on 6 and 8 days after the $2^{\text {nd }} \mathrm{HAL}$ challenge test, respectively. As showed in Fig. 6, quinpirole at 0.2 or $1.0 \mathrm{mg} / \mathrm{kg}$ increased motor activity during the 120-min test period, but rats previously treated with HAL throughout the adolescence did not seem to make more motor activity than those previously treated with vehicle. On the quinpirole $0.2 \mathrm{mg} / \mathrm{kg}$ test day, a split-plot ANOVA of the activity during each 10-min block (Fig. 6A) revealed a significant main effect of time-block $[F(11,198)=$ $41.529, p<0.001]$, but no main effect of group $[F(2,18)=2.362, p=0.123]$, nor block $\times$ group interaction $[F(22,429)=0.839, p=0.675]$. The group difference of the total motor activity in 120 min was also not significant (Fig. 6B), as one-way ANOVA showed no main effect of group, $F(2,18)=2.362, p=0.123$ ]. Similarly, on the quinpirole $1.0 \mathrm{mg} / \mathrm{kg}$ test day, the effect of time-block was significant $[F(11,198)=32.492, p<0.001]$, but not the effect of group $[F(2,18)=2.213, p=0.138]$, nor the block $\times$ group interaction $[F(22,429)=0.405, p$ $=0.993$; Fig. $6 \mathrm{C}]$. One-way ANOVA of the total motor activity in $120 \mathrm{~min}$ also did not find a significant group difference $[F(2,18)=2.213, p=0.138$; Fig. 6D]. These data suggest that adolescent HAL treatment may not have induced a long-lasting change in $\mathrm{D}_{2}$ receptor sensitivity.

\section{Discussion}

The present study is the first one to examine how different HAL dosing regimens affect the magnitude of HAL sensitization of its avoidance disruptive effect from adolescence to adulthood. This issue is significant given the highly plastic nature of adolescent brain and the increase use of antipsychotic drugs in adolescent patients in recent decades (Kalverdijk et al., 2008, Olfson et al., 2006, Rani et al., 2008). Our results show that different drug treatment schedules do affect the magnitude of HAL sensitization on avoidance responding. We found that only the HAL-0.05 INT group showed a robust sensitization, whereas rats in the HAL-0.25 CONT did not. On social functioning, adolescent HAL treatment did not affect social interaction and social recognition in adulthood, suggesting that HAL sensitization is a domain-specific effect and is restricted to drug sensitivity, not to other behavioral functions, a finding similar to our previous work (Qiao, Li, 2013). We also found that adolescent HAL treatment did not seem to cause a long-lasting change in $\mathrm{D}_{2}$ function in the quinpirole challenge test, suggesting that HAL sensitization may not be mediated by HAL-induced $\mathrm{D}_{2}$ upregulation. The present study adds to the literature by highlighting the importance of modes of drug administration in determining behavioral patterns of alterations in drug sensitivity in adolescence.

The main finding that only an intermittent HAL dosing regimen (i.e. daily injection) gave rise to a robust HAL sensitization in adulthood is consistent with previous comparative studies of these two modes of antipsychotic administration in adult rats (Samaha, Reckless, 2008, Samaha, Seeman, 2007). It has been shown that over time, daily HAL treatment tends to increase its efficacy to suppress conditioned avoidance responding, while continuous 
HAL treatment (via minipumps) gradually loses its efficacy. We did not observe an apparent tolerance effect under the HAL-0.25 CONT regimen as previously reported (Samaha, Reckless, 2008, Samaha, Seeman, 2007). One likely explanation is that we used the CS-only (no shock) procedure, while Samaha et al. (2008) used the CS-US procedure. The presence of footshock presumably caused a stronger motivation to avoid and a relearning process, both of which helped recovery from the suppression of HAL. The second explanation is the dose difference. The tolerance developed with HAL at $0.5 \mathrm{mg} / \mathrm{kg} /$ day (Samaha, Reckless, 2008), while it failed to develop at HAL $0.25 \mathrm{mg} / \mathrm{kg} / \mathrm{day}$. This point was also supported by the finding from the two HAL challenge tests: rats in the HAL-0.25 CONT group did not make significantly more avoidances than the vehicle rats. This dose-specific tolerance has been reported before with nicotine and amphetamine (Emmett-Oglesby and Goudie, 1989). The third possible explanation is the age of rats and the period when tolerance is assessed. It is possible that continuous HAL induces a stronger tolerance in adult rats (Samaha, Reckless, 2008) than in adolescent rats and this effect could not last over the adolescent period. Indeed, our previous work has shown that intermittent clozapine treatment can induce a tolerance effect on the avoidance response in adolescence or in adulthood, but not from adolescence to adulthood (Feng et al., 2013, Qiao, Li, 2013). In light of these findings, it is quite possible that $\mathrm{HAL}$ at $0.25 \mathrm{mg} / \mathrm{kg} / \mathrm{day}$ via minipumps did induce a tolerance in the treatment phase (the induction phase), which dissipated in the adulthood challenge phase (the expression phase). Future research should further investigate these issues.

One related question is to what extent that HAL induces a sensitization or tolerance depends on the mode of drug administration. Addressing this issue is significant to elucidate whether the antipsychotic sensitization or tolerance is drug specific or schedule-specific, as it touches on the essence of antipsychotic sensitization and tolerance. In all previous studies on adolescent and adult rats (Feng, Sui, 2013, Gao and Li, 2013, Li et al., 2012b, Li et al., 2010, Qiao, Li, 2013, Swalve and $\mathrm{Li}, 2012$, Zhang and Li, 2012), we only used the intermittent treatment schedule and found that antipsychotic sensitization and tolerance are drug-specific phenomena. Among several drugs that we tested, clozapine is the only one that causes a tolerance. Other drugs (e.g., haloperidol, olanzapine, risperidone and asenapine) always cause a sensitization (Gao and Li, 2013, Qiao, Gao, 2014a, Qin et al., 2013, Swalve and Li, 2012) when an intermittent treatment schedule is used. One important question is whether these drugs would also cause a different magnitude and behavioral pattern of drug responsiveness (sensitization vs. tolerance) in adolescent rats if they were administrated under different dosing schedule (e.g., intermittent vs. continuous). If drug-dosing schedule plays an important role in determining sensitization and tolerance patterns in adolescence, it is possible that we could observe tolerance with haloperidol, olanzapine, risperidone and asenapine when they are administrated on a continuous schedule. This issue is currently under investigation. On the basis of the present finding, we could conclude that HAL sensitization is a schedule-dependent phenomenon.

In the present study, we also examined how adolescent HAL treatment via minipump and injection affected social functioning in adulthood, one of seven primary cognitive domains that are impaired in schizophrenia (Floresco, Geyer, 2005, Green, Nuechterlein, 2004). We did this as a way to assess the clinical relevance of HAL sensitization, an issue that has not 
been explored so far. The rationale was that if the drug treatment regimen induces a sensitization and also impairs social functioning, these two behavioral effects are likely related. We examined the total social interaction time and two measurements of social working memory used a paradigm that we validated in amphetamine and phencyclidinebased animal models of schizophrenia (Li, He, 2012a). In this task, a subject rat was given multiple encounters with a juvenile partner rat in a new testing cage. The social working memory of rats was evidenced by the findings that a subject rat decreased its time investigating the same testing partner after a waiting period ( $10 \mathrm{~min})$ and increased its time on investigation if a novel partner was introduced (Akers et al., 2006, Holloway and Thor, 1988, Prediger et al., 2004). The finding that early HAL treatment did not leave a longlasting negative impact on social interaction and social working memory is in contrast to its acute effect (Li et al., 2004, Li et al., 2001, Zhao and Li, 2009). It is also different from other reports showing that continuous olanzapine treatment via drinking water $(7.5 \mathrm{mg} / \mathrm{kg} / \mathrm{day})$ from postnatal days 28 to 49 impairs cognitive function in the novel object recognition test (Llorente-Berzal et al., 2012) and impairs working memory in an delayed non-match to sample (DNMS) test (Milstein, Elnabawi, 2013). Besides the drug differences, the different ways of assessing working memory could also contribute to these discrepancies. This negative finding on social behavior, together with the demonstration of a robust HAL sensitization, suggests that there is dissociation between HAL-induced change in drug sensitivity and its effect on social and cognitive function.

To elucidate the possible neuroreceptor mechanisms underlying HAL sensitization, we used the quinpirole-induced hyperlomotion test. This test is a widely used method to assess drug or non-drug induced changes in $\mathrm{D}_{2}$ function (Tenk et al., 2007, Vorhees et al., 2009).

Because quinpirole is a preferential $\mathrm{D}_{2}$ receptor agonist, a higher level of motor activity under quinpirole challenge presumably reflects an upregulation of $\mathrm{D}_{2}$ receptor function (Luque-Rojas, Galeano, 2013, Moreno et al., 2005), and is also thought to be mediated through an increase in the efficacy of the post-synaptic $\mathrm{D}_{2}$ transduction (Szumlinski et al., 1997, Szumlinski et al., 2000). In our previous study on adult rats, we found that repeated risperidone treatment increased the quinpirole-induced hyperlocomotion: risperidone-treated rats exhibited a significantly higher level of motor activity than the vehicle-pretreated ones under the quinpirole $(1.0 \mathrm{mg} / \mathrm{kg}$, sc) challenge, suggesting that risperidone sensitization induced in adult rats is likely mediated by $\mathrm{D}_{2}$ receptor upregulation. However, when the same approach was applied to adolescent rats, we failed to observe the increased quinpiroleinduced hyperlocomotion: adult rats previously treated with risperidone in adolescence did not make more motor activity than those previously treated with vehicle. Similarly in the present study, both intermittent and continuous HAL treatments did not seem to cause a long-lasting upregulation of $\mathrm{D}_{2}$ receptor. All these results suggest that dopamine $\mathrm{D}_{2}$ receptors may not mediate the across-adolescence antipsychotic sensitization. In fact, our previous pharmacological study suggests that HAL sensitization may involve its action on 5$\mathrm{HT}_{2 \mathrm{~A} / 2 \mathrm{C}}$ receptor system, as concurrent treatment of DOI (a 5- $\mathrm{HT}_{2 \mathrm{~A} / 2 \mathrm{C}}$ receptor agonist), rather than quinpirole, attenuates HAL sensitization (Li, Sun, 2010). This conclusion is also supported by the findings that HAL is a $5-\mathrm{HT}_{2 \mathrm{~A}}$ receptor inverse agonist (Weiner et al., 2001), and repeated HAL treatment causes a reduction in $5-\mathrm{HT}_{2 \mathrm{~A}}$ receptor mRNA expression in various limbic regions (Buckland et al., 1997). It is possible that HAL causes a 
sensitization effect by down-regulating of 5- $\mathrm{HT}_{2 \mathrm{~A}}$ receptor. On the other hand, the presumed tolerance effect induced by continuous HAL treatment (Samaha, Reckless, 2008, Samaha, Seeman, 2007) might be mediated by its action on $D_{2}$ receptors, as continuous HAL treatment causes a greater increase in striatal $D_{2}$ receptor numbers, especially the $D_{2}$ receptors in a high-affinity state for dopamine than intermittent HAL treatment (Samaha, Reckless, 2008, Samaha, Seeman, 2007). One important task for future research is to determine the relative roles of various neuroreceptors that are targeted by HAL in the mediation of the induction and expression of HAL sensitization under an intermittent schedule and the possible HAL tolerance under a continuous schedule.

There are several limitations in the present study. First, because this work has used otherwise healthy male rats, it remains to be elucidated whether HAL sensitization can also be demonstrated in "diseased" animals and how this sensitization effect may manifest itself differently in normal animals versus animal models of schizophrenia. Previous work has shown that adolescent antipsychotic treatment has differential effects in normal and "diseased" animals. For instance, adolescent risperidone or clozapine treatment prevents the development of various psychosis-like behaviors (e.g. prepulse inhibition deficit, latent inhibition deficit, etc.) induced by maternal immune activation (PolyI:C injection during pregnancy), while impairing certain behavioral functions of normal animals (Meyer, Spoerri, 2010, Piontkewitz, Arad, 2011, Piontkewitz, Assaf, 2009, Piontkewitz, Bernstein, 2012). To address this issue, we need to test antipsychotic drugs in adolescent animal models of schizophrenia. Second, only one dose of HAL was tested in adolescent rats, it is not known whether the same dose-dependent HAL sensitization as demonstrated in adult rats can be demonstrated in adolescent rats. Also, the quinpirole challenge tests were conducted after HAL challenge tests, which could potentially mask HAL-induced functional change in $\mathrm{D}_{2}$ receptor. Future work should consider these limitations and extend the current findings to other antipsychotic drugs in animal models of schizophrenia. Another research direction is to determine the clinical significance of HAL treatment in adolescence. Because cognitive and negative symptoms of schizophrenia are also likely affected by antipsychotic treatment (Terry et al., 2003), it is of great importance in the future work to examine how different antipsychtoic dosing regimens affect basic cognition and negative symptoms-like behaviors in rats using tests such as novel object recognition, reversal learning, attentional set shifting, and social behaviors, etc.

\section{Acknowledgments}

We would like to thank Mr. Rongyin Qin for his help on running the conditioned avoidance training. This study was supported by the National Institute of Mental Health of the National Institutes of Health under award number R01MH085635 to Professor Ming Li.

\section{Abbreviations}

$\begin{array}{ll}\text { ANOVA } & \text { analysis of variance } \\ \text { CAR } & \text { conditioned avoidance response } \\ \text { CS } & \text { conditioned stimulus }\end{array}$




$\begin{array}{ll}\text { CONT } & \text { continuous } \\ \text { HAL } & \text { haloperidol } \\ \text { HAL-0.05 INT } & \text { intermittent haloperidol } 0.05 \mathrm{mg} / \mathrm{kg} \\ \text { HAL-0.25 CONT } & \text { continuous HAL } 0.25 \mathrm{mg} / \mathrm{kg} / \text { day } \\ \text { INT } & \text { intermittent } \\ \text { PND } & \text { postnatal day } \\ \text { PolyI:C } & \text { polyinosinic-polycytidylic acid sodium salt, US, unconditioned } \\ & \text { stimulus } \\ \text { VEH } & \text { vehicle }\end{array}$

\section{References}

Agid O, Kapur S, Arenovich T, Zipursky RB. Delayed-onset hypothesis of antipsychotic action: a hypothesis tested and rejected. Arch Gen Psychiatry. 2003; 60:1228-1235. [PubMed: 14662555]

Akers KG, Nakazawa M, Romeo RD, Connor JA, McEwen BS, Tang AC. Early life modulators and predictors of adult synaptic plasticity. Eur J Neurosci. 2006; 24:547-554. [PubMed: 16903856]

Arnt J. Pharmacological specificity of conditioned avoidance response inhibition in rats: inhibition by neuroleptics and correlation to dopamine receptor blockade. Acta Pharmacol Toxicol (Copenh). 1982; 51:321-329. [PubMed: 6129770]

Buckland PR, D'Souza U, Maher NA, McGuffin P. The effects of antipsychotic drugs on the mRNA levels of serotonin 5HT2A and 5HT2C receptors. Brain Res Mol Brain Res. 1997; 48:45-52. [PubMed: 9379848]

Emmett-Oglesby, MW.; Goudie, AJ. Psychoactive drugs : tolerance and sensitization. Clifton, N.J: Humana Press; 1989.

Fallon P, Dursun SM. A naturalistic controlled study of relapsing schizophrenic patients with tardive dyskinesia and supersensitivity psychosis. J Psychopharmacol. 2011; 25:755-762. [PubMed: 20147573]

Feng M, Sui N, Li M. Environmental and behavioral controls of the expression of clozapine tolerance: Evidence from a novel across-model transfer paradigm. Behav Brain Res. 2013; 238:178-187. [PubMed: 23092709]

Floresco SB, Geyer MA, Gold LH, Grace AA. Developing predictive animal models and establishing a preclinical trials network for assessing treatment effects on cognition in schizophrenia. Schizophr Bull. 2005; 31:888-894. [PubMed: 16079387]

Gao J, Li M. Time-dependence of risperidone and asenapine sensitization and associated D2 receptor mechanism. Behav Brain Res. 2013; 257:286-294. [PubMed: 24103641]

Green MF, Nuechterlein KH, Gold JM, Barch DM, Cohen J, Essock S, et al. Approaching a consensus cognitive battery for clinical trials in schizophrenia: the NIMH-MATRICS conference to select cognitive domains and test criteria. Biol Psychiatry. 2004; 56:301-307. [PubMed: 15336511]

Holloway WR Jr, Thor DH. Social memory deficits in adult male rats exposed to cadmium in infancy. Neurotoxicol Teratol. 1988; 10:193-197. [PubMed: 3211096]

Kalverdijk LJ, Tobi H, van den Berg PB, Buiskool J, Wagenaar L, Minderaa RB, et al. Use of antipsychotic drugs among Dutch youths between 1997 and 2005. Psychiatr Serv. 2008; 59:554560. [PubMed: 18451016]

Kapur S, Agid O, Mizrahi R, Li M. How antipsychotics work-from receptors to reality. NeuroRx. 2006; 3:10-21. [PubMed: 16490410] 
Kapur S, VanderSpek SC, Brownlee BA, Nobrega JN. Antipsychotic dosing in preclinical models is often unrepresentative of the clinical condition: a suggested solution based on in vivo occupancy. J Pharmacol Exp Ther. 2003; 305:625-631. [PubMed: 12606608]

Li M, Budin R, Fleming AS, Kapur S. Effects of chronic typical and atypical antipsychotic drug treatment on maternal behavior in rats. Schizophr Res. 2005; 75:325-336. [PubMed: 15885524]

Li M, Davidson P, Budin R, Kapur S, Fleming AS. Effects of typical and atypical antipsychotic drugs on maternal behavior in postpartum female rats. Schizophrenia research. 2004; 70:69-80. [PubMed: 15246466]

Li M, He W, Munro R. Differential effects of acute amphetamine and phencyclidine treatment and withdrawal from repeated amphetamine or phencyclidine treatment on social interaction and social memory in rats. PsyCh Journal. 2012a; 1:56-68.

Li, M.; Kapur, S.; Fleming, A. International Congress on Schizophrenia Research. Canada: Whistler Resort, British Columbia; 2001. Antipsychotics interfere with maternal and social behaviors in rats: Differential effects of haloperidol and clozapine; p. 93

Li M, Sun T, Mead A. Clozapine, but not olanzapine, disrupts conditioned avoidance response in rats by antagonizing 5-HT(2A/2C) receptors. J Neural Transm. 2012b; 119:497-505. [PubMed: 21986871]

Li M, Sun T, Zhang C, Hu G. Distinct neural mechanisms underlying acute and repeated administration of antipsychotic drugs in rat avoidance conditioning. Psychopharmacology. 2010; 212:45-57. [PubMed: 20623111]

Llorente-Berzal A, Mela V, Borcel E, Valero M, Lopez-Gallardo M, Viveros MP, et al. Neurobehavioral and metabolic long-term consequences of neonatal maternal deprivation stress and adolescent olanzapine treatment in male and female rats. Neuropharmacology. 2012; 62:13321341. [PubMed: 21819999]

Luque-Rojas MJ, Galeano P, Suarez J, Araos P, Santin LJ, de Fonseca FR, et al. Hyperactivity induced by the dopamine D2/D3 receptor agonist quinpirole is attenuated by inhibitors of endocannabinoid degradation in mice. The international journal of neuropsychopharmacology / official scientific journal of the Collegium Internationale Neuropsychopharmacologicum. 2013; 16:661-676.

Meyer U, Spoerri E, Yee BK, Schwarz MJ, Feldon J. Evaluating early preventive antipsychotic and antidepressant drug treatment in an infection-based neurodevelopmental mouse model of schizophrenia. Schizophr Bull. 2010; 36:607-623. [PubMed: 18845557]

Milstein JA, Elnabawi A, Vinish M, Swanson T, Enos JK, Bailey AM, et al. Olanzapine treatment of adolescent rats causes enduring specific memory impairments and alters cortical development and function. PLoS One. 2013; 8:e57308. [PubMed: 23437365]

Moreno M, Lopez-Moreno JA, Rodriguez de Fonseca F, Navarro M. Behavioural effects of quinpirole following withdrawal of chronic treatment with the CB1 agonist, HU-210, in rats. Behavioural pharmacology. 2005; 16:441-446. [PubMed: 16148449]

Nakamura S, Yue JL, Goshima Y, Miyamae T, Ueda H, Misu Y. Non-effective dose of exogenously applied L-dopa itself stereoselectively potentiates postsynaptic D2 receptor-mediated locomotor activities of conscious rats. Neuroscience letters. 1994; 170:22-26. [PubMed: 7913743]

Olfson M, Blanco C, Liu L, Moreno C, Laje G. National trends in the outpatient treatment of children and adolescents with antipsychotic drugs. Arch Gen Psychiatry. 2006; 63:679-685. [PubMed: 16754841]

Piontkewitz Y, Arad M, Weiner I. Risperidone administered during asymptomatic period of adolescence prevents the emergence of brain structural pathology and behavioral abnormalities in an animal model of schizophrenia. Schizophr Bull. 2011; 37:1257-1269. [PubMed: 20439320]

Piontkewitz Y, Assaf Y, Weiner I. Clozapine administration in adolescence prevents postpubertal emergence of brain structural pathology in an animal model of schizophrenia. Biol Psychiatry. 2009; 66:1038-1046. [PubMed: 19726031]

Piontkewitz Y, Bernstein HG, Dobrowolny H, Bogerts B, Weiner I, Keilhoff G. Effects of risperidone treatment in adolescence on hippocampal neurogenesis, parvalbumin expression, and vascularization following prenatal immune activation in rats. Brain, behavior, and immunity. 2012; 26:353-363. 
Prediger RD, Batista LC, Miyoshi E, Takahashi RN. Facilitation of short-term social memory by ethanol in rats is mediated by dopaminergic receptors. Behav Brain Res. 2004; 153:149-157. [PubMed: 15219716]

Qiao J, Gao J, Shu Q, Zhang Q, Hu G, Li M. Long-lasting sensitization induced by repeated risperidone treatment in adolescent Sprague-Dawley rats: a possible D2 receptor mediated phenomenon? Psychopharmacology. 2014a; 231:1649-1659. [PubMed: 24363078]

Qiao J, Li H, Li M. Olanzapine sensitization and clozapine tolerance: from adolescence to adulthood in the conditioned avoidance response model. Neuropsychopharmacology. 2013; 38:513-524. [PubMed: 23132270]

Qiao J, Zhang Q, Li M. Long-term impacts of adolescent risperidone treatment on behavioral responsiveness to olanzapine and clozapine in adulthood. Prog Neuropsychopharmacol Biol Psychiatry. 2014b; 48:177-185. [PubMed: 24140929]

Qin R, Chen Y, Li M. Repeated asenapine treatment produces a sensitization effect in two preclinical tests of antipsychotic activity. Neuropharmacology. 2013; 75:356-364. [PubMed: 23954676]

Rani F, Murray ML, Byrne PJ, Wong IC. Epidemiologic features of antipsychotic prescribing to children and adolescents in primary care in the United Kingdom. Pediatrics. 2008; 121:10021009. [PubMed: 18450906]

Remington G, Kapur S. Antipsychotic dosing: how much but also how often? Schizophr Bull. 2010; 36:900-903. [PubMed: 20650931]

Samaha AN, Reckless GE, Seeman P, Diwan M, Nobrega JN, Kapur S. Less is more: antipsychotic drug effects are greater with transient rather than continuous delivery. Biol Psychiatry. 2008; 64:145-152. [PubMed: 18295747]

Samaha AN, Seeman P, Stewart J, Rajabi H, Kapur S. "Breakthrough" dopamine supersensitivity during ongoing antipsychotic treatment leads to treatment failure over time. J Neurosci. 2007; 27:2979-2986. [PubMed: 17360921]

Shu Q, Hu G, Li M. Adult response to olanzapine or clozapine treatment is altered by adolescent antipsychotic exposure: a preclinical test in the phencyclidine hyperlocomotion model. $\mathrm{J}$ Psychopharmacol. 2014; 28:363-375. [PubMed: 24257809]

Strange PG. Antipsychotic drugs: importance of dopamine receptors for mechanisms of therapeutic actions and side effects. Pharmacol Rev. 2001; 53:119-133. [PubMed: 11171942]

Swalve N, Li M. Parametric studies of antipsychotic-induced sensitization in the conditioned avoidance response model: roles of number of drug exposure, drug dose, and test-retest interval. Behav Pharmacol. 2012; 23:380-391. [PubMed: 22732209]

Szumlinski KK, Allan M, Talangbayan H, Tracey A, Szechtman H. Locomotor sensitization to quinpirole: environment-modulated increase in efficacy and context-dependent increase in potency. Psychopharmacology. 1997; 134:193-200. [PubMed: 9399384]

Szumlinski KK, Goodwill AM, Szechtman H. Locomotor sensitization to quinpirole in rats: effects of drug abstinence and sex. Psychopharmacology. 2000; 152:304-311. [PubMed: 11105941]

Tenk CM, Foley KA, Kavaliers M, Ossenkopp KP. Neonatal immune system activation with lipopolysaccharide enhances behavioural sensitization to the dopamine agonist, quinpirole, in adult female but not male rats. Brain, behavior, and immunity. 2007; 21:935-945.

Terry AV Jr, Hill WD, Parikh V, Waller JL, Evans DR, Mahadik SP. Differential effects of haloperidol, risperidone, and clozapine exposure on cholinergic markers and spatial learning performance in rats. Neuropsychopharmacology. 2003; 28:300-309. [PubMed: 12589383]

Turrone P, Remington G, Kapur S, Nobrega JN. Continuous but not intermittent olanzapine infusion induces vacuous chewing movements in rats. Biol Psychiatry. 2005; 57:406-411. [PubMed: 15705357]

Vorhees CV, Johnson HL, Burns LN, Williams MT. Developmental treatment with the dopamine D2/3 agonist quinpirole selectively impairs spatial learning in the Morris water maze. Neurotoxicol Teratol. 2009; 31:1-10. [PubMed: 18930132]

Wadenberg ML, Hicks PB. The conditioned avoidance response test re-evaluated: is it a sensitive test for the detection of potentially atypical antipsychotics? Neurosci Biobehav Rev. 1999; 23:851862. [PubMed: 10541060] 
Wadenberg ML, Soliman A, VanderSpek SC, Kapur S. Dopamine D(2) receptor occupancy is a common mechanism underlying animal models of antipsychotics and their clinical effects. Neuropsychopharmacology : official publication of the American College of Neuropsychopharmacology. 2001; 25:633-641. [PubMed: 11682246]

Weiner DM, Burstein ES, Nash N, Croston GE, Currier EA, Vanover KE, et al. 5hydroxytryptamine2A receptor inverse agonists as antipsychotics. J Pharmacol Exp Ther. 2001; 299:268-276. [PubMed: 11561089]

Zhang C, Li M. Contextual and behavioral control of antipsychotic sensitization induced by haloperidol and olanzapine. Behavioural pharmacology. 2012; 23:66-79. [PubMed: 22157143]

Zhao C, Li M. The receptor mechanisms underlying the disruptive effects of haloperidol and clozapine on rat maternal behavior: a double dissociation between dopamine $\mathrm{D}(2)$ and 5-HT(2A/2C) receptors. Pharmacology, biochemistry, and behavior. 2009; 93:433-442. 


\section{Highlights}

1. Intermittent haloperidol treatment in adolescence induced a behavioral sensitization.

2. Continuous haloperidol treatment in adolescence did not induce a sensitization.

3. Adolescent haloperidol under both regimens did not impair social behavior and memory.

4. Adolescent haloperidol under both regimens did not affect long-lasting $\mathrm{D}_{2}$ function. 


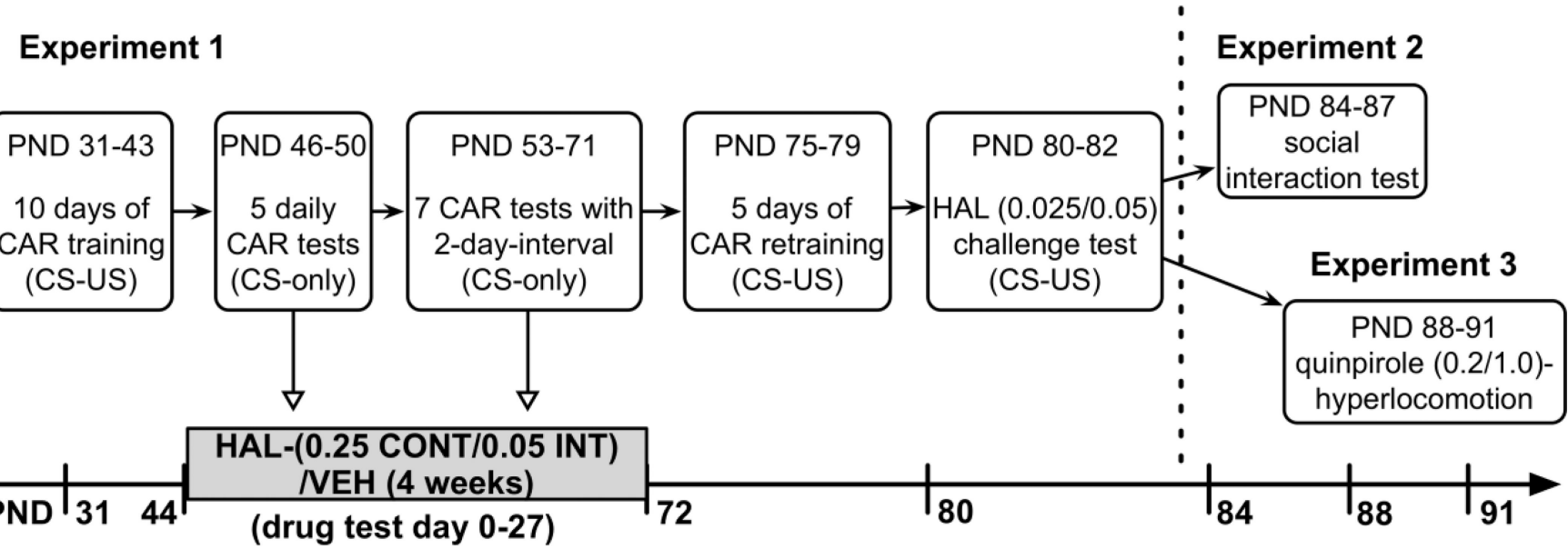

Fig. 1.

Schematic illustration of the experimental procedure used in this study. Major events are indicated. 


\section{VEH $\rightarrow$ HAL-0.25 CONT $\neg$ HAL-0.05 INT}

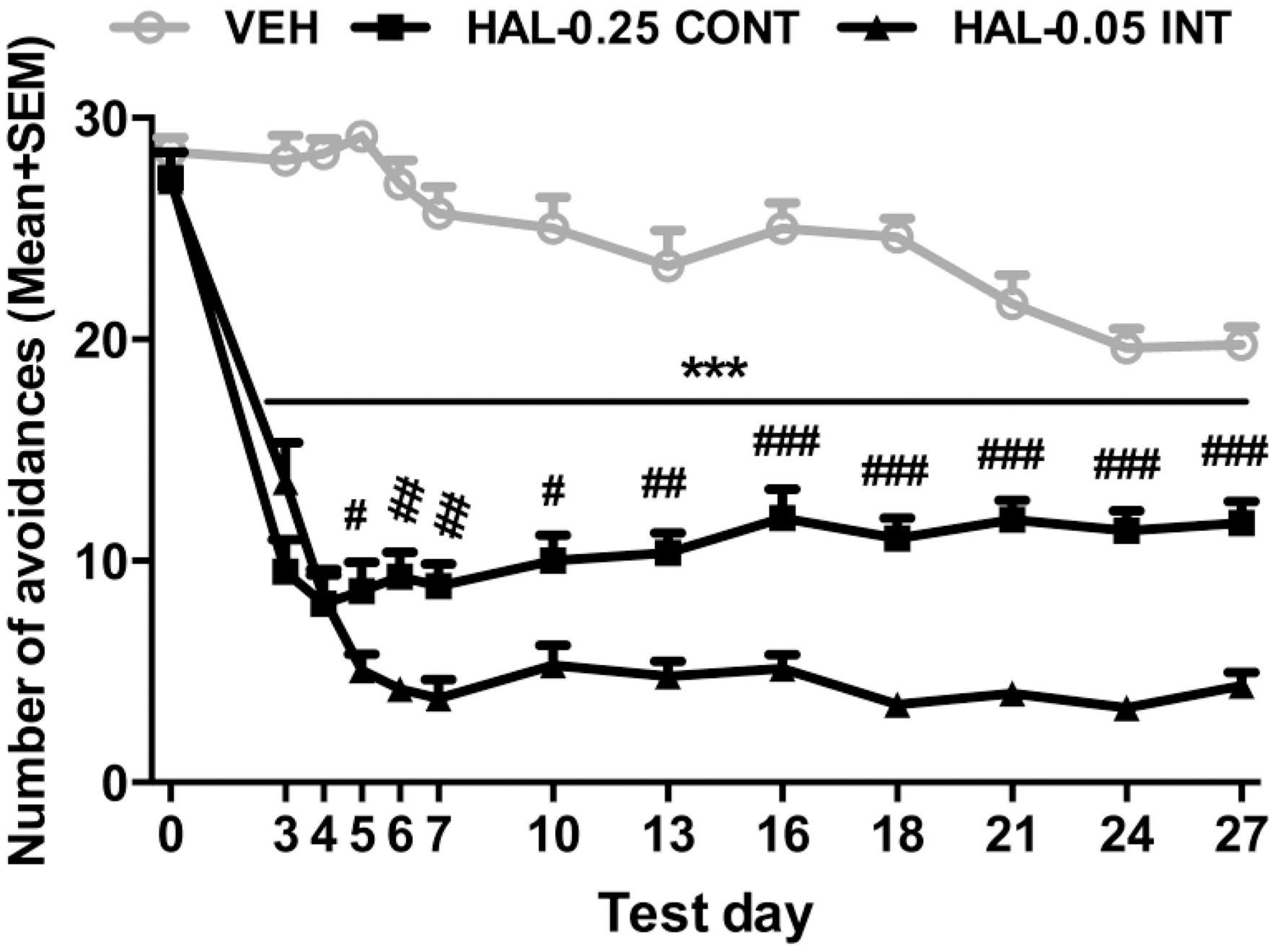

Fig. 2.

Effects of chronic continuous versus intermittent haloperidol treatment on conditioned avoidance responding over time. Number of avoidance responses made by the rats treated with HAL-0.25 CONT ( $0.25 \mathrm{mg} / \mathrm{kg} /$ day via minipump, $\mathrm{n}=14)$, HAL-0.05 INT (0.05 $\mathrm{mg} / \mathrm{kg} /$ injection/day sc, $\mathrm{n}=14$ ) or vehicle $(\mathrm{VEH}, \mathrm{n}=13$ ) on the predrug $(0)$ day, and drug test days. ${ }^{* * *} p<0.001$ for comparisons between HAL-(0.05 INT and 0.25 CONT) and VEH; ${ }^{\# \#} p<0.001,{ }^{\# \#} p<0.01,{ }^{\#} p<0.05$ for comparisons between HAL-0.05 INT and HAL-0.25 CONT on each test day. 


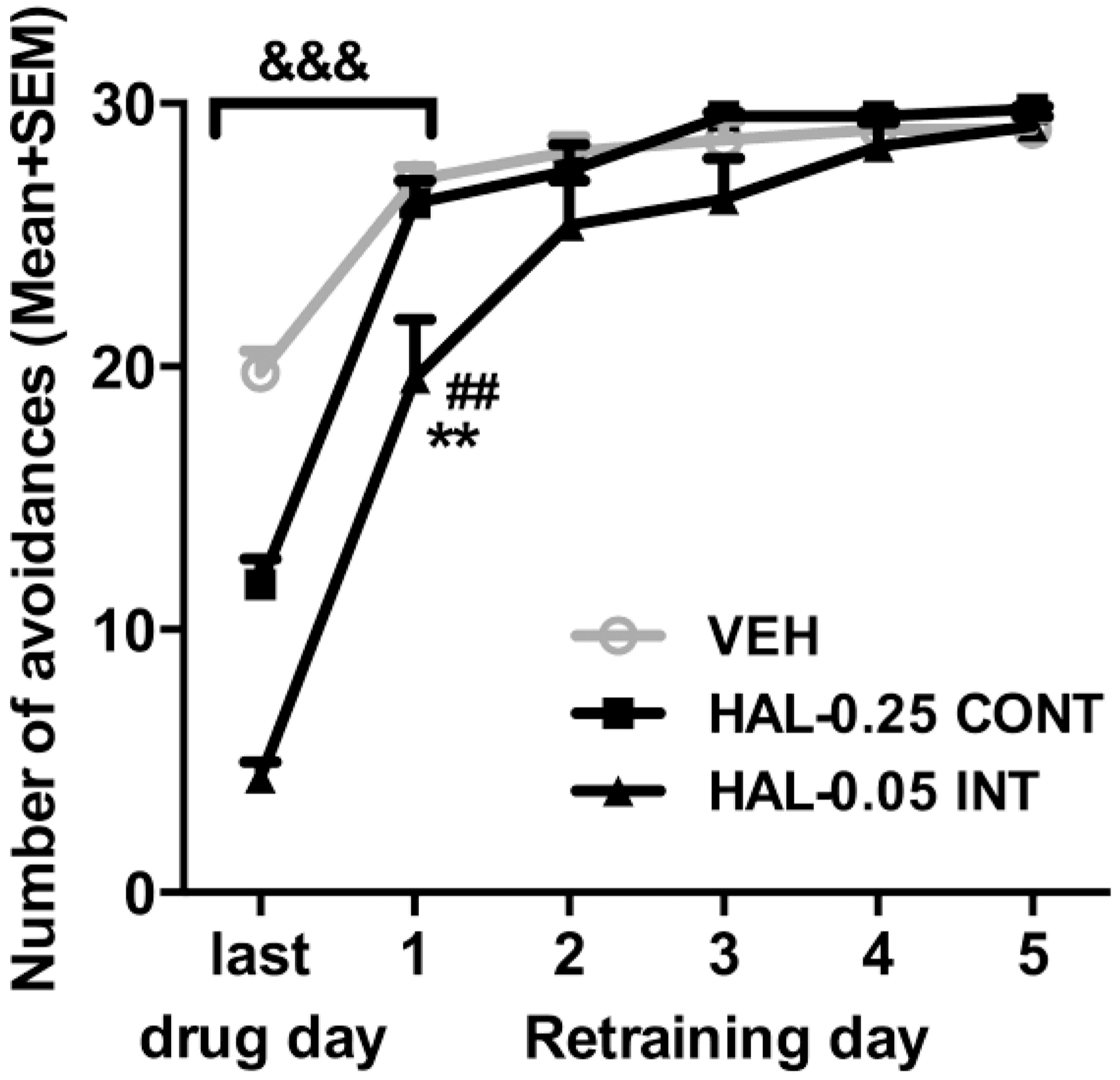

Fig. 3.

Number of avoidance responses made by the rats previously treated with HAL- 0.25 CONT $(0.25 \mathrm{mg} / \mathrm{kg} /$ day via minipump, $\mathrm{n}=14)$, HAL-0.05 INT $(0.05 \mathrm{mg} / \mathrm{kg} /$ injection/day $\mathrm{sc}, \mathrm{n}=$ 14 ) or vehicle (VEH, $\mathrm{n}=13$ ) on the last drug test day and the five retraining days. ${ }^{* *} p<0.01$ for comparisons between HAL-0.05 INT and VEH; ${ }^{\# \#} p<0.01$ for comparisons between HAL-0.05 INT and HAL-0.25 CONT on each day; \&\&\&ps < 0.001 for comparisons between the last drug day and first retraining day in each group. 
A Challenged by HAL $0.025 \mathrm{mg} / \mathrm{kg}$

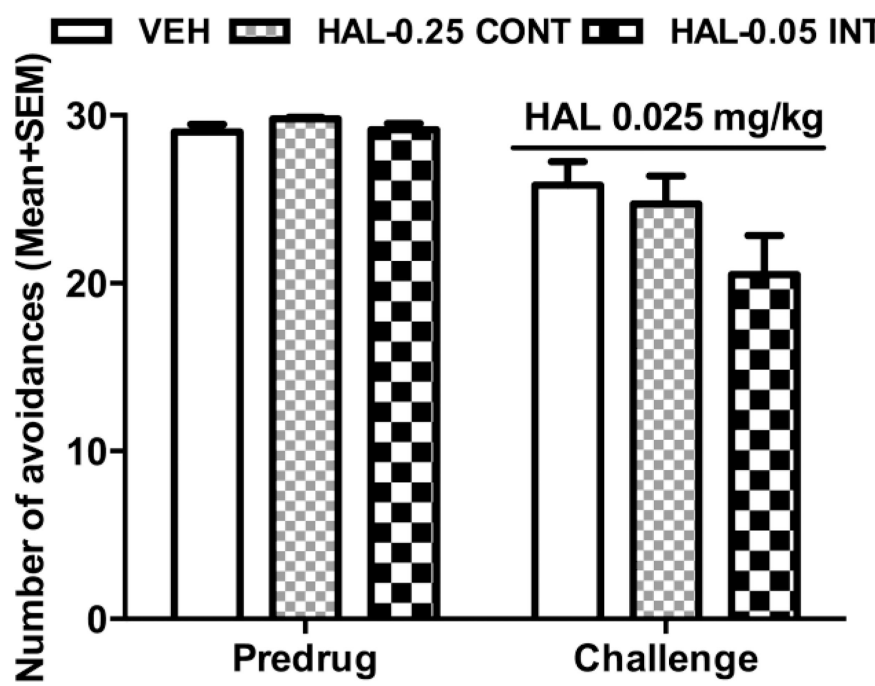

B Challenged by HAL $0.05 \mathrm{mg} / \mathrm{kg}$

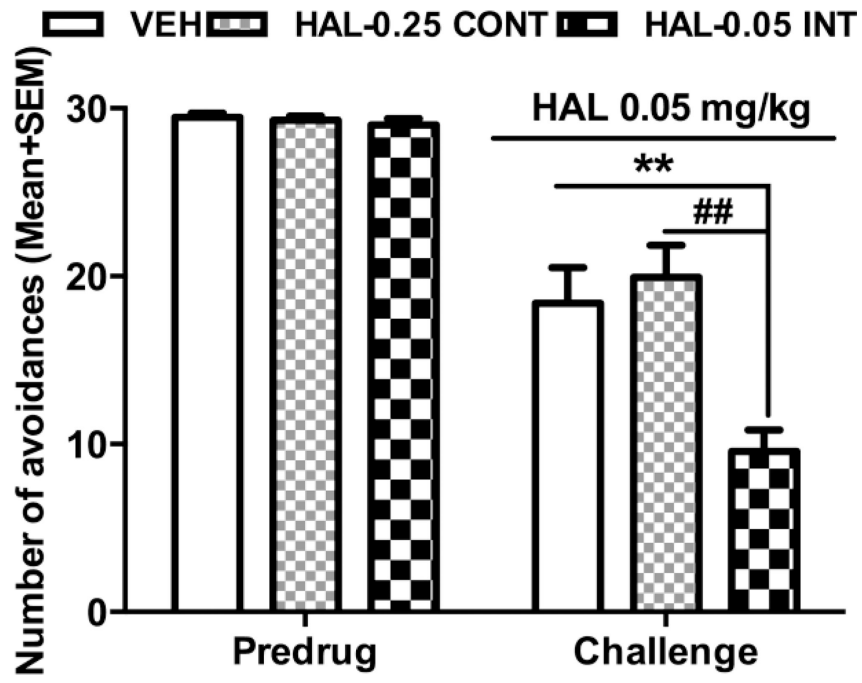

Fig. 4.

Number of avoidance responses made by the 3 groups of rats in the HAL $0.025 \mathrm{mg} / \mathrm{kg}$ (A) or $0.05 \mathrm{mg} / \mathrm{kg}$ (B) challenge tests. After retraining, all groups were injected with HAL at 0.025 and $0.05 \mathrm{mg} / \mathrm{kg}$ (sc) 9 and 11 days after the last HAL treatment, respectively. Avoidance tests were conducted 60 min later. All data are expressed as mean + SEM. ${ }^{* *} p<$ 0.01 for comparison to the VEH group; ${ }^{\# \#} p<0.01$ for comparison to the HAL-0.05 INT group. 

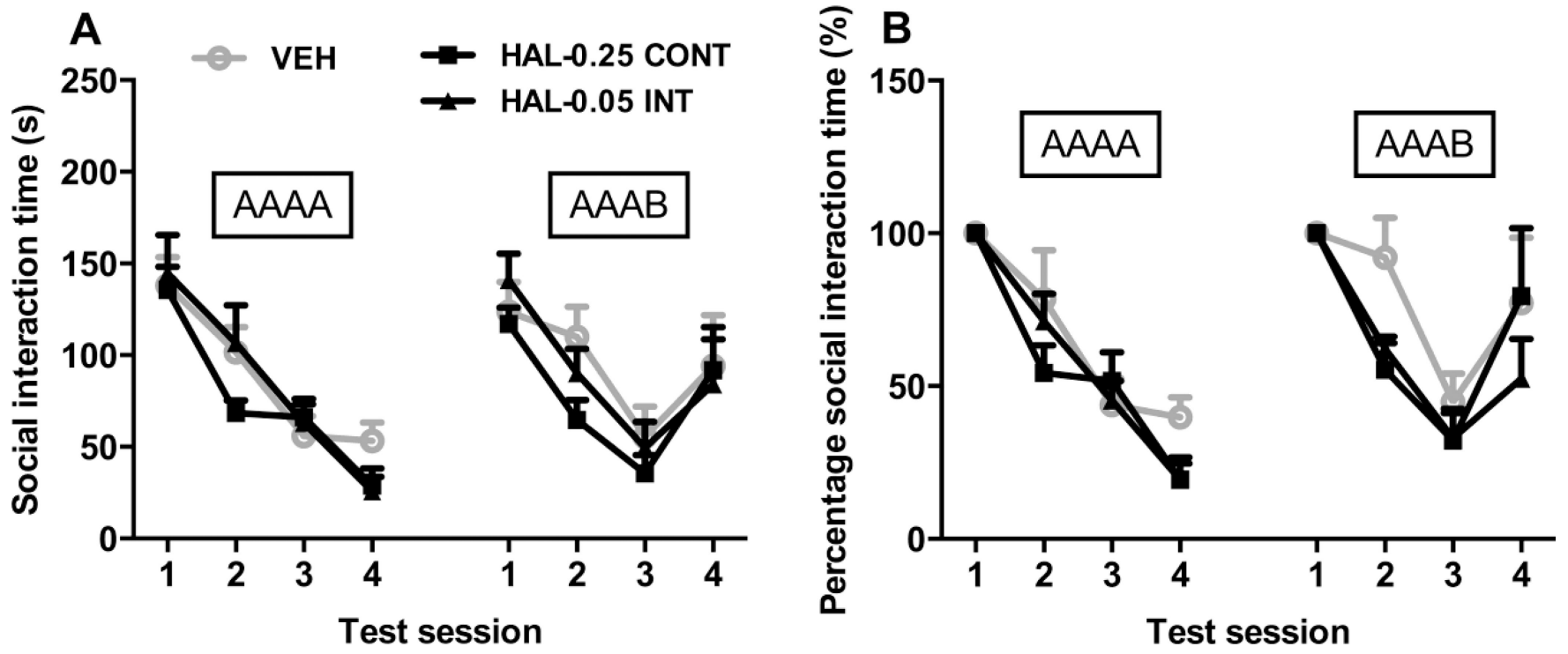

Fig. 5.

Long-term effects of chronic continuous versus intermittent haloperidol treatment throughout adolescence on social behavior in adulthood. Social interaction time in seconds (A) and percentage of social interaction time (B) are shown. Social interaction tests were conducted over 2 days for each rat. On the first day, the same test partner was used in the 4 5-min sessions separated by a 10-min interval (denoted as AAAA day). On the second day, the same test partner was used in the first 3 sessions, and a new partner was used in the fourth session (denoted as AAB). The percentage of social interaction time for each individual rat was calculated by dividing the time spent on social interaction in sessions 2-4 by the time spent in the first session. All data are expressed as mean + SEM. 

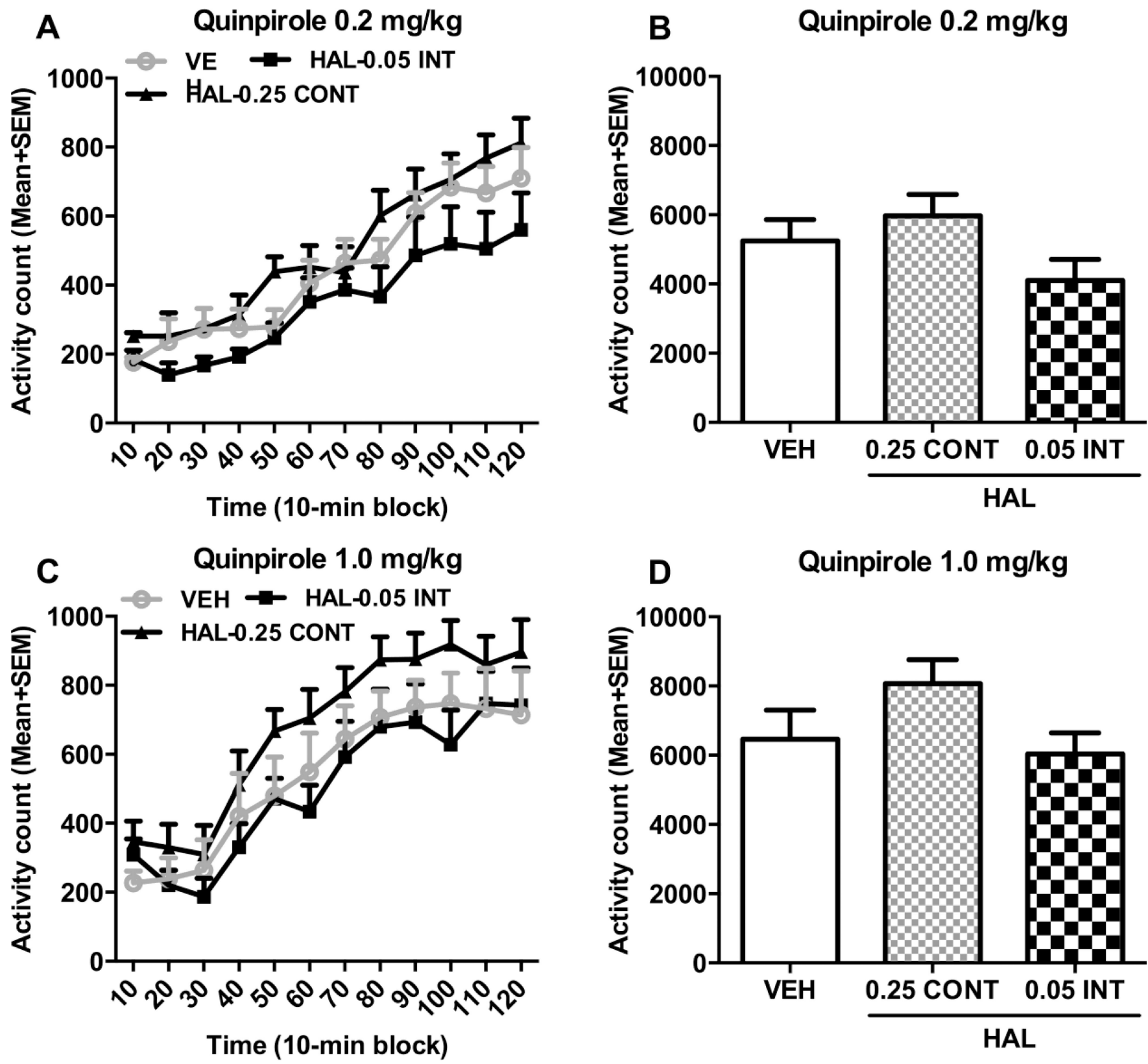

Fig. 6.

Long-term effects of chronic continuous versus intermittent haloperidol treatment throughout adolescence on quinpirole-induced hyperlocomotion. Quinpirole-induced locomotor activity was measured in 1210 - min blocks $(A, C)$ or totaled in $120 \mathrm{~min}(\mathrm{~B}, \mathrm{D})$. All rats that were pretreated with HAL-0.25 CONT, HAL-0.05 INT, or VEH ( $\mathrm{n}=7$ /group) were injected with quinpirole at $0.2(\mathrm{~A}, \mathrm{~B})$ or $1.0(\mathrm{C}, \mathrm{D}) \mathrm{mg} / \mathrm{kg}(\mathrm{sc})$ and then measured for motor activity for $120 \mathrm{~min}$. The tests were conducted 6 and 8 days after the last HAL challenge test, respectively. All data are expressed as mean + SEM. 